\title{
Transformational Government Citizens' Services Adoption: A Conceptual Framework
}

\author{
Teta Stamati ${ }^{1}$, Thanos Papadopoulos ${ }^{2}$, and Drakoulis Martakos ${ }^{1}$ \\ ${ }^{1}$ Department of Informatics and Telecommunications, National and Kapodistrian University of \\ Athens, Panepistimiopolis, Ilissia 15784, Greece \\ \{teta, martakos\} adi.uoa.gr \\ ${ }^{2}$ Knowledge and Information Systems Management Group, Centre for Operational Research \\ Management Science and Information Systems (CORMSIS), School of Management \\ University of Southampton, SO17 1BJ Southampton, UK \\ a.papadopoulos@soton.ac.uk
}

\begin{abstract}
Despite the need expressed in the literature for shedding light upon the mechanisms that underpin the transformational process of t-Government, there is still research to be conducted regarding the critical factors that affect the citizens' adoption of local government transformational services. To address this gap, this research reports on the findings of the use of the structured-case approach and suggests a framework to investigate the success factors for t-Gov in a Greek context. The paper reveals that transformational government is not a state, but a process entailing experiential judgement. Existing acceptance theories, hence, need to be complemented by additional variables that affect citizens' adoption of transformational services.
\end{abstract}

Keywords: Transformational government, interpretivist school, theory building.

\section{Introduction}

The successful delivery of public policy is increasingly dependent upon the effective use and application of new technologies and Information Systems (IS) [1]. However, significant issues are raised when policy conceptualizations travel through the many and often labyrinthine levels of public administration. To address these issues and change the way citizens interact and communicate with each other, as well as to enhance the relationship between citizens and government, transformational government (t-Gov) comes to the fore [2][3][4].

The study reports on the use of the structured-case approach to investigate the success factors for a massive Greek t-Gov initiative in Greek Local Government Organisations (LGOs) to investigate the parameters that ensure the smooth use of the Local Government Application Framework (LGAF) [5]. The paper outlines the contribution of the structured-case approach to build t-Gov theory following the interpretivist approach [5] [6] [7] [8] [9]. The structure of the paper is as follows: after a brief review of t-Gov and factors affecting its success, the research methods and context of the study are discussed. It follows the discussion of the study results and the presentation of the improved framework. The last section concludes the paper. 


\section{Technology Acceptance Theories}

Past research on e-Gov has focused on implementation by using diffusion models. In particular, research has used Diffusion of Innovation (DOI) Theory [10]. Relevant studies [11] [12] [13] [14] focusing on the role of administration size and professionalism on the adoption of computer technology [15]. Furthermore, literature has referred to the IS Success Model [16] and the Technology Acceptance Model (TAM) [17] as another means for discussing the particularities of the e-Gov implementation by measuring perceived usefulness (PU) and perceived ease of use (PEOU). TAM [17], based on the Theory of Reasoned Action (TRA) [18], is one of the most well established theoretical frameworks that describe how users accept and use a technology [19]. The factors discussed by the TAM [20] [21] [22] have been utilised in various studies of acceptance of technology, IS, [23] [24] and e-commerce [25] [26] [27]. Building on these TAM versions, the Unified Theory of Acceptance and Use of Technology (UTAUT) was introduced by [28], consisting of three factors namely performance expectancy, effort expectancy, and social influence and relevant studies have emerged [29] [30] However, Paul et al. [31] suggest that TAM is not conclusive and suffers from the absence of factors regarding social and human processes. Moreover, PEOU is not consistently linked to adoption [25] [32] [33] [23]. Finally, TAM is criticised for representing subjective user assessments of a system [15] [30].

Literature [34] [30] suggests that since there are many similarities between ecommerce and e-Gov, TAM factors in e-commerce [25] [26] [27] [35] could be used in the case of e-Gov [30]. However, the use of TAM has not been used extensively in the case of t-Gov, taking under consideration its nature [36] [37]. Therefore, this study aims to: understand the factors that affect citizens' adoption and on going usage of LGAF, and suggest a conceptual model explaining the dynamics of citizens and acceptance of the LGAF.

\section{Motivation for the Study}

This paper uses LGAF to study the smooth implementation of t-Gov. LGAF reshapes access to information by integrating almost two hundred and fifty electronic government services in many different domains of the public administration such as in health, social care, education, public transportation, cultural, and other sectors and creates various organizational and technological constraints [39] [40] [41] [42]. LGAF is Greek/European co-funded initiative for the Central Union of Municipalities and Communities of Greece (www.kedke.gr). It aims to bring together the central and local governments, the private sector, and the society, by providing advanced, secure, privacy-aware, interoperable, and high-administrative national electronic services.

\section{Research Method and Case Description}

This research follows the interpretive paradigm [6] [43] [7] [44] [8] [45] [9]. The authors adopted a methodological approach based on the structured-case research method [46] [47] [48] [49][50]. 


\subsection{Conceptual Framework (CF1)}

The limited research undertaken regarding LGOs' citizens adoption of transformational services enforced the authors mainly to use TAM as baseline to develop the initial CF1. The initial CF1 (Figure 1) includes constructs derived from the literature and existing technology acceptance theories.

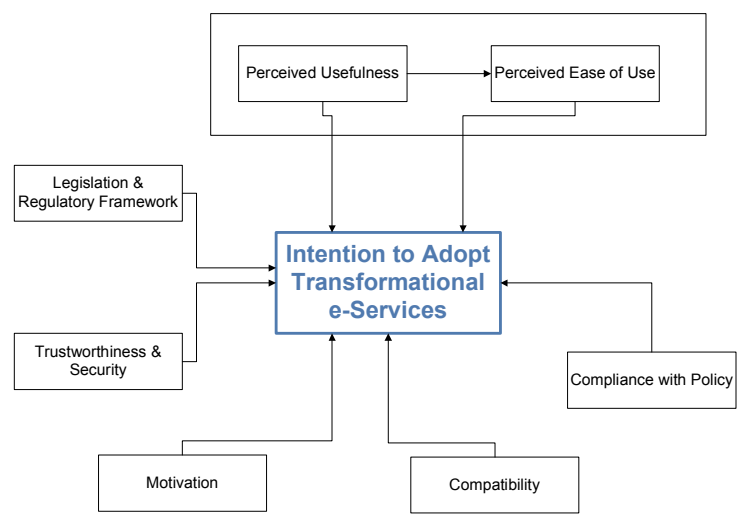

Fig. 1. Initial Conceptual Framework for Transformational Government

The model attempts to capture the complex relationships involved in t-Gov services adoption. Apart from PU and PEOU, the adoption of t-Gov services raises important political, cultural, organizational, technological, human and social issues. CF1 thus includes:

Ease of Use: significant field research has taken place the past two decades regarding the effects that the construct PEOU has on both PU and intention to use [19] [51]. Hence, PEOU will have a positive effect on both PU and behavioral intention to keep using LGAF.

Usefulness: Individual behavioral intention to use a provided service is strongly affected by users' PU [19] [51] [52]. Hence, it is likely that high citizens' PU will lead them to positive evaluation of the necessity of LGAF.

Motivation: Potential individual differences in motivation to use a technological innovation were suggested to be one of the most relevant variables in the adoption and use [53] [54]. Active use of new technology with greater motivation has been found to produce stronger behavioral effects on the use of it [55].

Compatibility: Based on DOI, authors consider as an important proposition the fact that higher levels of perceived compatibility are associated with increased intentions to adopt t-Gov. Users will be willing to use services congruent with their preferred way of interaction [30].

Legislation and Regulatory Framework: Current legislation frameworks are characterized by the assignment of significant powers to public bodies and the recognition of relevant formal guarantees for citizens, based typically on observance 
by public administrations of a legally predetermined bureaucratic-based sequence of steps. Many rules become barriers to the effective implementation of $\mathrm{t}-\mathrm{Gov}$ and erode its confidence among citizens, since they are made too rigid to accommodate the changes by ICT professionals.

Trustworthiness and Security: perceived trustworthiness and security are considered as a significant construct. Trustworthiness can be divided into "trust to the initiative" and "trust to the LGO" [56] The authors hypothesize that higher levels of perceived trustworthiness are positively related to intention to use LGAF, considering past studies on trust, security, and technological innovations [30] [57].

Compliance with Policy: The authors suggest that governmental policy can establish communication channels that may either promote citizens' adoption and use of t-Gov services, or induce resistance [19] [58].

\subsection{Methodological Approach of the Research Cycle}

The first research cycle aimed to validate and further revise the CF1. The case studies took place in twelve LGOs that participated as 'pilots' LGOs. A variety of primary (e.g. interviews) and secondary data sources, such as internal and technical reports for LGOs operations and requirements were used. A two-day workshop took place in five different places around Greece with the participation of total of two hundred and fifty stakeholders (experts from the LGOs, the Greek Ministry of Interior, the ICT industry and people from the local regions) (Table 1). Based on these data, the authors synthesized a set of key factors that citizens consider as important. Afterwards, a set of requirements for the effective design and implementation of LGAF were consolidated as the first user scenarios. During the workshops, more than fifty in number, regional and national individual interviews, were conducted with the LGOs employees, the chief technology officers, the administrators, the consultants, and the citizens as potential users. The duration of each interview was approximately forty five minutes.

\section{Findings and Discussion}

The data analysis demonstrates that adoption agenda is influenced by a combination of issues at the individual level. Hence, a multi-disciplinary approach is essential to its investigation and research, involving an effective management of systems, information, policies, processes, and change. To this point, debates during the workshops were about the fit of technology on LGOs' processes and operations rather that developing the right technology. Some of the variables identified in the CF1 were found to be inter-reliant. The authors followed the classification of t-Gov terminology and attempted to group the findings as human and social constructs, organizational constructs and technical constructs, allowing for more specific concepts to emerge within such groupings. 
Table 1. Workshops' participation

\begin{tabular}{|c|c|c|c|}
\hline Workshops & Duration & Participants No & Profile of Participants \\
\hline WS1 & $\begin{array}{l}\text { 1st day: } 6 \mathrm{~h} \\
\text { 2nd day: } 5 \mathrm{~h}\end{array}$ & 65 & $\begin{array}{l}\text { Male: } 58 \text {; Female: } 24 \\
\text { Academia: 7; LGOs: } 31 \text {; } \\
\text { Industry: } 13 \text {; Citizens: } 30\end{array}$ \\
\hline WS2 & $\begin{array}{l}\text { 1st day: } 5 \mathrm{~h} \\
\text { 2nd day: } 4 \mathrm{~h}\end{array}$ & 47 & $\begin{array}{l}\text { Male: } 19 \text {; Female: } 12 \\
\text { Academia: 1; LGOs: 12; } \\
\text { Industry: 9; Citizens: } 9\end{array}$ \\
\hline WS3 & $\begin{array}{l}\text { 1st day: } 5 \mathrm{~h} \\
\text { 2nd day: } 5 \mathrm{~h}\end{array}$ & 40 & $\begin{array}{l}\text { Male: } 37 \text {; Female: } 22 \\
\text { Academia: 1; LGOs: } \\
\text { Industry: 5; Citizens: } 29\end{array}$ \\
\hline WS4 & $\begin{array}{l}\text { 1st day: } 6 \mathrm{~h} \\
\text { 2nd day: } 4 \mathrm{~h}\end{array}$ & 36 & $\begin{array}{l}\text { Male: } 17 \text {; Female: } 21 \\
\text { Academia: 3; LGOs: } 16 \text {; } \\
\text { Industry: 8; Citizens: } 11\end{array}$ \\
\hline WS4 & $\begin{array}{l}\text { 1st day: } 5 \mathrm{~h} \\
\text { 2nd day: } 3 \mathrm{~h}\end{array}$ & 36 & $\begin{array}{l}\text { Male: } 26 \text {; Female: } 16 \\
\text { Academia: } 3 ; \quad \text { LGOs: 21; } \\
\text { Industry: } 11 \text {; Citizens: } 7\end{array}$ \\
\hline
\end{tabular}

Human and Social Constructs: "Compatibility" was found to have a significant relationship with use intentions in t-Gov. The participants strongly suggested that LGAF should operate in a manner that "is consistent with individuals' values, beliefs and experiences" and provide information and work support in a manner that is "consistent with what citizens are used on".

Another significant concern was "trustworthiness". Citizens, who perceived the reliability and security of the internet to be low, presented obstacles when using LGAF [57]. There was a long debate between participants in the workshops regarding the notion of initial trust to LGAF that refers to "trust in an unfamiliar trustee, a relationship in which the actors do not yet have credible, meaningful information about, or affective bonds with, each other" [57]. Regarding trustworthiness, citizens who perceived Greek government to be trustworthy consider the introduction of LGAF as a welcome initiative. Governmental-based trust was mainly associated with citizens' perceptions of the governmental environment, such as the structures, regulations and legislation that make an individual feel safe and trustworthy [59].

Another important construct was the motivation or the perceived need for working 'over the wire'. In demographic terms, the data analysis revealed that a percentage of $76 \%$ of the interviewees stated they intend to immediate use LGAF (early LGAF adopters) were people in young age, more educated $(80 \%$ of them holding a University degree) and with relatively high incomes (40\% of them had a net family income more than thirty thousand per year). This indicated that individual demographic characteristics were also influencing the adoption of provided services. The cases analysis proved that a group of individuals were more likely to keep using LGAF than others. Consequently, we examined two factors namely, the level of prior Internet usage and the citizens innovativeness. Individual innovativeness can be defined as 'consumer acceptance' of new ideas [4]. The findings supported that higher Internet usage led to LGAF adoption. Domain-specific innovativeness, i.e. innovation linked to certain domains was found to influence LGAF adoption. Finally, there was a group of users persuaded very quickly of the LGAF's significant advantages 
compared to prior institutional systems. This proved that individual perceived relative advantage enforced the individual intention to use.

Organizational Constructs: The discussions concerned the coordination and ownership between and across LGOs and departments, the political engagement regarding the delivery of technology supported services, the LGO capacity including available resources (human, technical, etc.), change and risk management issues as well as the appropriate legal and legislation framework. Participants discussed about the nature and mission of LGOs and their relationship with the electronic services provided. There was a clear concern regarding potential future developments and change [4]. Clear policies for LGOs were seen to be critical. Key issues included sense of ownership and the required organisational transformation. A key concern was about ways to cope with organisational inertia. A particularly important area of risk was the access to governmental services and the issue of community inclusion. Furthermore, it emerged that measurement and evaluation techniques were necessary to realise the learning perspectives of t-Gov. To achieve successful transformational implementations it is necessary to establish coherent legitimacy and establish trust relationships between government and citizens. Since the legal framework regarding the provision of electronic services is 'still in infancy', a cohesive legal framework is required to speed the adoption of $\mathrm{t}-\mathrm{Gov}$. The research has revealed that four main sets of legislation are considered: personal data protection laws; privacy and security laws; information (provision) laws; and administrative laws.

Technical Constructs: Various technical parameters that might affect LGAF adoption and regular use were revealed. The supporting staff in LGOs stressed the need for a less complex framework and more user-friendly in its user interface, and the forms and templates. The majority of interviewers and workshop participants were sceptical about the use of innovative technological tools, by aged users; the authors labelled this attribute 'computer anxiety'. IT experts identified the need for flexible and scalable technology, privacy and security, shared services and common identity management, standards, coordination and integration between LGOs operations and departments, identification and authentication. Regarding the notions of scalability and flexibility of governmental systems, the cases revealed that there is need to create flexible systems that can adapt and change on demand in accordance to the changing nature of t-Gov [2] [3]. There was no definite agreement regarding what constitutes valid and appropriate access to information. Finally, issues of interoperability and standardisation arose, stemming from the way different LGO's departments can be managed, the technical tools needed for integration and the standardisation of certain data and services. To this extend, the notions of open standards and open source software were highlighted.

\subsection{Conceptual Framework (CF2)}

The research findings resulted in the modification of the CF1 to a revised framework (CF2) (Figure 2). 


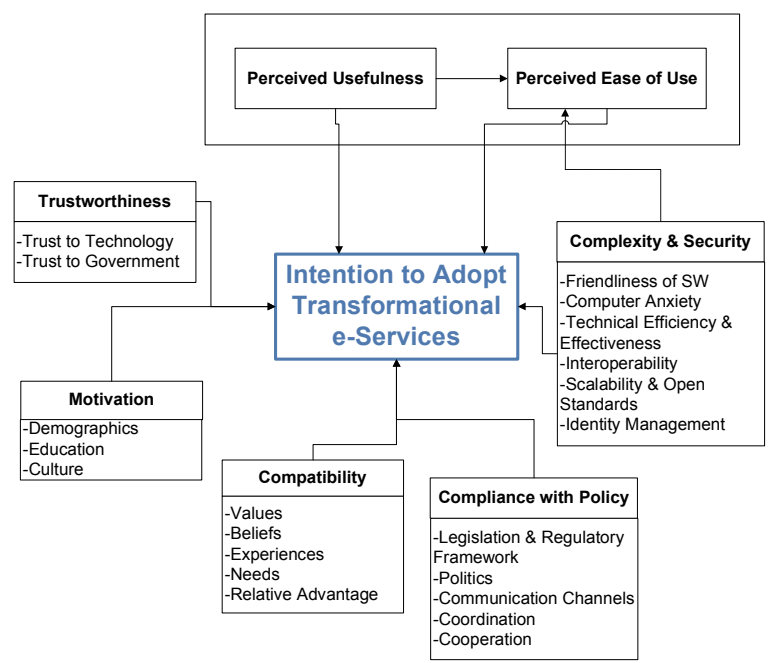

Fig. 2. Final Conceptual Framework for Transformational Government

The proposed CF2 can be used as the basis for further research. The adoption of LGAF from citizens is presented as the initial crucial step in the diffusion process for government to capture its goals, enable an environment for social and economic growth, and contribute to the process of transformation of the Greek local administration towards a leaner and cost-effective administration. The real benefit of LGAF lies not in the use of technological framework per se, but in its application to processes of transformation in the Greek bureaucratic public sector.

\section{Conclusions}

T-Gov initiatives have been identified as one of the top central government priorities. Citizens' acceptance of LGAF raises important political, cultural, organisational, technological and social issues that must be considered carefully. In this research a framework which consists of concepts and details about the key adoption factors of tGov was developed, which can be used as a tool to determine the roadmap for adoption of a t-Gov initiative. Further research could include the study of how the perceived attributes of trialability and observability may affect the adoption of transformational services by citizens. Although the nature of the study does not allow the generalisation of findings, we could suggest that future research should also aim at exploring the applicability of this framework to other e-government projects.

\section{References}

1. Papadopoulos, T., Kanellis, P.: Public Sector Reform Using Information Technologies: Transforming Policy into Practice. IGI Publishing (forthcoming, 2011)

2. Janssen, M., Shu, W.S.: Transformational government: basics and key issues. In: Janowski, T., Pardo, T.A. (eds.) Proceedings of the 2nd International Conference on Theory and Practice of Electronic Governance. ACM International Conference Proceeding Series, vol. 351, pp. 117-122. ACM Publications, Cairo (2008) 
3. Irani, Z., Elliman, T., Jackson, P.: Electronic Transformation of government in the U.K.: a research agenda. European Journal of Information Systems 16, 327-335 (2008)

4. Irani, Z., Love, P.E.D., Elliman, T., Jones, S., Themistocleous, M.: Evaluationg egovernment: learning from the experiences of two UK local authorities. Information Systems Journal 15, 61-82 (2005)

5. LGAF project: Local Government Application Framework. 6th Framework Programme, http://wiki.kedke.org/wiki/

6. Walsham, G.: The emergence of interpretivism in IS research. Information Systems Research 6(4), 376-394 (1995)

7. Denzin, N.K., Lincoln, Y.S.: Collecting and interpreting qualitative materials. Sage Publications, Thousand Oaks (1989)

8. Lee, A., Baskerville, R.: Generalizing in information systems research. Information Systems Research 14(3), 221-243 (2003)

9. Oates, B.J.: Researching information systems and computing. Sage Publications, Thousand Oaks (2006)

10. Grönlund, A.: Ten years of E-government: The 'End of history" and new beginning. In: Wimmer, M.A., Chappelet, J.-L., Janssen, M., Scholl, H.J. (eds.) EGOV 2010. LNCS, vol. 6228, pp. 13-24. Springer, Heidelberg (2010)

11. Rogers, E.M.: Diffusion of Innovations. Free Press, New York (1995)

12. Moon, M.J.: The evolution of e-Government among municipalities: Rhetoric or reality? Public Administration Review 62(4), 424-433 (2002)

13. Moon, J., Norris, D.: Does managerial orientation matter? The adoption of reinventing government and e-government at the municipal level. Information Systems Journal 15, 43$60(2005)$

14. Norris, D.F., Campillo, D.: Factors Affecting Innovation Adoption by City Governments: The Case of Leading Edge Information Technologies, Maryland Institute for Policy Analysis and Research. University of Maryland, Baltimore (2000)

15. Angelopoulos, S., Kitsios, F., Papadopoulos, T.: Identifying Critical Success Factors in eGovernment: A New service development approach. Transforming Government: People, Process and Policy 4(1), 95-118 (2010)

16. DeLone, W.H., McLean, E.R.: Information systems success: The quest for the dependent variable. Information Systems Research 3(1), 60-95 (1992)

17. Davis, F.: Perceived usefulness, perceived ease of use and user acceptance of information technology. MIS Quarterly 13, 319-340 (1989)

18. Ajzen, I., Fishbein, M.: Attitudes and normative beliefs as factors influencing intentions'. Journal of Personality and Social Psychology 21, 1-9 (1972)

19. Davis, F.D., Bagozzi, R.P., Warshaw, P.R.: User acceptance of computer technology: A comparison of two theoretical models. Management Science 35(8), 982-1003 (1989)

20. Benbasat, I., Barki, H.: Quo vadis TAM. Journal of the Association for Information Systems 8(4), 211-218 (2007)

21. King, W.R., He, J.: A meta-analysis of the technology acceptance model. Information \& Management 43, 740-755 (2006)

22. Schepers, J., Wetzels, M.: A meta-analysis of the technology acceptance model: investigating subjective norm and moderation effects. Information \& Management 44, 90 103 (2007)

23. Venkatesh, V., Davis, F.: A theoretical extension of the technology acceptance model: four longitudinal field studies. Management Science 46, 186-204 (2000) 
24. Venkatesh, V., Morris, M.G.: Why don't men ever stop to ask for directions? Gender, social influence, and their role in technology acceptance and usage behavior. MIS Quarterly 24(1), 115-139 (2000)

25. Gefen, D., Straub, D.: The relative importance of perceived ease of use in IS adoption: a study of e-commerce adoption. Journal of the Association for Information Systems 1, 1-28 (2000)

26. Moon, J., Kim, Y.: Extending the TAM for a World-Wide-Web context. Information \& Management 38(4), 217-230 (2001)

27. Gefen, D., Karahanna, E., Straub, D.: Trust and TAM in online shopping: an integrated model. MIS Quarterly 27, 51-90 (2003)

28. Venkatesh, V., Morris, M.G., Davis, G.B., Davis, F.D.: User acceptance of information technology: Toward a unified view. MIS Quarterly 27(3), 425-478 (2003)

29. Shajari, M., Ismail, Z.: A comprehensive adoption model of e-Government services in developing countries. In: IEEE International Conference Advanced Management Science (ICAMS), vol. 2, pp. 548-553 (2010)

30. Carter, L., Bélanger, F.: The utilization of e-government services: citizen trust, innovation and acceptance factors. Information Systems Journal 15, 5-25 (2005)

31. Paul, L., John, I., Pierre, C.: Why do people use information technology? A critical review of the technology acceptance model. Association for Information Systems 40(3), 191 (2003)

32. Ma, Q., Liu, L.: The Technology Acceptance Model: A Meta-Analysis of Empirical Findings. Journal of Organizational and End User Computing 16(1), 59-72 (2004)

33. Taylor, S., Todd, P.A.: Assessing IT Usage: The Role of Prior Experience. MIS Quarterly 19(4), 561-570 (1995)

34. Barzilai-Nahon, K., Scholl, J.: Siblings of a Different Kind: E-Government and ECommerce. In: IFIP e-Government Conference (August 2010)

35. Pavlou, P.: Consumer acceptance of electronic commerce: integrating trust and risk with the technology acceptance model. International Journal of Electronic Commerce 7, 69-103 (2003)

36. Sipior, J., Ward, B., Connolly, R.: The digital divide and t-government in the United States: using the technology acceptance model to understand usage. European Journal of Information Systems 19(1), 1-21 (2010)

37. Pilling, D., Boletzig, H.: Moving toward egovernment - effective strategies for increasing access and use of the internet among non-internet users in the U.S. and U.K. In: Cushing, J.B., Pardo, T.A. (eds.) Proceedings of the 8th Annual International Conference on Digital Government Research: Bridging Disciplines \& Domains Philadelphia. ACM International Conference Proceeding Series 228 Digital Government Research Center 2007, pp. 35-46. ACM Publications, New York (2007)

38. Weerakkody, V., Janssen, M., Hjort-Madsen, K.: Realising Integrated E-Government Services: A European Perspective. Journal of Cases in Electronic Commerce 3(2), 14-38 (2007)

39. Fulk, J.: Social construction of communication technology. Academy of Management Journal 36, 921-950 (1993)

40. Fulk, J., Schmitz, J., Steinfield, C.W.: A social influence model of technology use Organizations and Communication Technology. Sage, Newbury Park (1990)

41. Kling, R.: Learning about information technologies and social change: The contribution of social informatics. The Information Society 16(3), 217-232 (2000)

42. Williams, R., Edge, D.: The social shaping of technology, Information and Communication Technologies: Visions and Realities. Oxford University Press, New York (1996) 
43. Remenyi, D.: Doing research in business and management: an introduction to process and method. Sage Publications, Thousand Oaks (1998)

44. Hussey, J., Hussey, R.: Business research: a practical guide for undergraduate and postgraduate students. Macmillan Business, Basingstoke (1997)

45. Myers, M.D.: Qualitative research in information systems. Management Information Systems Quarterly 21(2), 241-242 (1997)

46. Carroll, J., Dawson, L.L., Swatman, P.A.: Using Case Studies to Build Theory: Structure and Rigour. In: At Proceedings of 9th Australasian Conference on Information Systems, University of NSW, Sydney (1998)

47. Carroll, J., Swatman, P.: Structured-case: a methodological framework for building theory in information systems research. European Journal of Information Systems 9, 235-242 (2000)

48. Neuman, W.L.: Social Research Methods: Qualitative and Quantitative Approaches. Allyn and Bacon, Boston (1991)

49. Gummerson, E.: Qualitative Methods in Management Research. Sage, Thousand Oaks (1991)

50. Galliers, R.D.: Reflection on Information Systems: Twelve Points to Debate. In: Mingers, J., Stowell, F. (eds.) Information Systems: An Emerging Discipline, McGraw-Hill, Berkshire (1997)

51. Hu, P.J., Chau, P.Y.K., Sheng, O.R.L., Tam, K.Y.: Examining the technology acceptance model using physician acceptance of telemedicine technology. Journal of Management Information Systems 16, 91-112 (1999)

52. Jackson, C.M., Chow, S., Leitch, R.A.: Toward an understanding of the behavioural intentions to use an information system. Decision Sciences 28, 357-389 (1997)

53. Hong, W., Thong, J.Y.L., Wong, W.-M., Tam, K.-Y.: Determinants of user acceptance of digital libraries: An empirical examination of individual differences and system characteristics. Journal of Management Information Systems 18(3), 97-124 (2002)

54. Stafford, M.R., Stern, B.: Consumer bidding behavior on Internet auction sites. International Journal of Electronic Commerce 7(1), 135-150 (2002)

55. Rubin, A.M.: The uses-and-gratifications perspective of media effects. Media Effects: Advances in Theory and Research, 2nd edn. Lawrence Erlbaum Associates, Mahwah (2002)

56. Bélanger, F., Hiller, J., Smith, W.: Trustworthiness in electronic commerce: the role of privacy, security, and site attributes. Journal of Strategic Information Systems 11, 245-270 (2002)

57. McKnight, H., Choudhury, V., Kacmar, C.: Developing and validating trust measures for ecommerce: an integrative typology. Information Systems Research 13, 334-359 (2002)

58. Dutton, W.H., Cheong, P.H., Park, N.: An ecology of constraints on e-learning in higher education: The case of virtual learning environment. Prometheus 22(2), 131-149 (2004)

59. Lee, M., Turban, E.: A trust model for internet shopping. International Journal of Electronic Commerce 6, 75-91 (2001) 